\title{
SerikiAbass: Slave Trade, Badagry, and the History That Refuses To Die
}

\author{
Anago James Akeem Osho ${ }^{1}$ \\ Curator and Tour-Guide,SerikiFaremiWilliam Abass Museum,Badagry, Lagos, Nigeria.
}

\begin{abstract}
There are usually many faces to history; or of what we term "history" always exhumes from our past. History then becomes our own way of coming to terms with certain realities that shaped our lives, and sometimes continue to shape our perception about both the past and the present. In this paper, I examine that kind of history, which continues to be relevant: the history of SerikiFaremi Williams Abassand the Brazilian Baracoon of 40 Slaves located in Badagry. This ancient edifice, which he left behind, continues to serve as the memory of his person and the trans-Atlantic Slave Trade including the role of Badagry. The paper argues that although the slave trade remains a harrowing experience for the thousands of people sold into slavery during the time, there is also in that experience thedemonstration of the human capacity to transcend beyond itself so people can continue to learn from them.
\end{abstract}

Keywords: Badagry,Baracoon, Point of No Return,Seriki Williams Abass, trans-Atlantic Slave Trade.

\section{INTRODUCTION}

History, according to Keith Byerman, includes imagined or actual events that occurred in the past, and dealing with a family or community, contains historiographical accounts, or hypothetical events that reflect conditions or circumstances. Needless to say that history goes beyond these concerns however, "history" could also mean the stories of ordinary people in times of stress, which take into account their dehumanization, and represent a shared experience of suffering rather than a genetic or geographical connection that shapes group identity, or the ordeal of a certain hero(ine) (Byerman, 8)[1].Such is the nature and concern of history.However, thehistory that I am interested in here is the historiographical one based on the Middle Passage; the events of the trans-Atlantic Slave Trade. Specifically, it is the story ofSerikiFaremi William Abass and the Brazilian Baracoon of 40 Slaves that he left behind. Out of four of such Baracoons located at Posukoh, Ahovikoh, Awhajigor and Jegba quarters all in Badagry, it is only SerikiAbass' that still stands today.

Although this edifice has since been assumed by the Lagos State government and conferred the status of a museum by the Nigerian National Commission for Museum and Monument, itremains the most concrete evidenceof SerikiAbassand of the trans-Atlantic Slave Trade in the West coast of Nigeria, especially in Badagry, with which he was identified.This article aims to open the discussion on the man and his ancient, yet "modern" building and slave relic known as the Baracoon of 40 Slaves. Ancient because it tells stories of the past, and modern because it is one story that comes alive, is renewed and retold every day to thousands of tourists, who have visited the place in the past, and still do today. Contemporary events have made it very clear that it is very difficult to tell the story of this slave relic without first revisiting that of the man behind it.

\section{BADAGRY IN THE CONTEXT OF THE SLAVE TRADE}

The trans-Atlantic Slave Trade has been classified into two phases: the first part dealt with the shipping of enslaved Africans to the Portuguese and Spanish empires of the South American colonies beginning from around 1502 until 1580 when Portugal temporarily merged with Spain; and the second phase was largely dominated by the English, Portuguese, French and Dutch slave traders who chose Caribbean colonies of Brazil and other parts of the New World. This period lasted between 1450 and 1600. By the 1690s, the English were the most prominent slave dealers in the trans-Atlantic trade.

\footnotetext{
${ }^{1}$ Anago is an award-winning trained tour guide, poet, historian, and creative artist, drummer and dancer who holds an Advanced Diploma in Tour-Guiding and Certificate in Training on Best Practices on Tour-Guiding, from UNIDO, UNEP, UNWTO etc. 
Of the areas namely, Togo, Benin and Yorubaland in Nigeria, West of the Niger Delta, Badagry remains a major point of reference about the trans-Atalantic Slave Trade, having claimed its place as both a slave relic and historical site of significant reference. Badagry is situated between metropolitan Lagos and the border with Benin Republic at Seme. As of the preliminary 2006 census results, the population of Badagry was put at about 241,093.Itinhabitsthe Agia tree under which Christianity was said to havefirst beenpreached in that part of the world, the supposed "first storey building" where Bishop AjayiCrowther translated the Holy Bible into Yoruba language, and the Vlekete slave marketto mention a few. Lying in the west coast of Lagos together with a number of other Yoruba and Aja-speaking areas, Badagry remains a port and former small city-state, whose early history of origin was mired in a controversy attributed to a Dutch trader, Hertoug's account of 1736. Although Badagry did not have a real port other than a canoe port, because of its location on the mainland shore, seagoing vessels were able to move off the shoreacross the lagoon (Falola,259)[2]. However, some earlier works of history treated Badagry as a part of Egbado even though it became part of the Colony of Lagos in 1863. Because of its strategic location, Badagrybenefitted from both local and international trade and rose to become a major slave port by the 1720s under the control of the Oyo Empire which used the Olu of Ilaro as its political agent to control trade in the area and other parts of Egbado. But suffering defeat in the hands of Dahomey in the 1780s, Badagry and the southwest Yorubaland were drawn into the crises and wars which disruptedlife generally. In spite of the wars however, Badagry remained an important trade terminus (Slave Trade most especially) for the most part of the $19^{\text {th }}$ century (Falola,237-8; Biobaku,1957; Ayantuga,1965;Folayan,1967; Law,1977)[3][4][5][6]. The history of SerikiFaremi Williams Abass and his Brazilian Baracoon of 40 slaves remains a significant source of establishing the truth of that account, and of recalling a specific time in history whose narrative contributes to our understanding of that ignominious past.

\section{SERIKIABASS A HISTORY OF BADAGRYTHAT}

\section{REFUSES TO BE FORGOTTEN}

Not much has been written about SerikiFaremi Williams Abass. It is as if there is a deliberate attempt to obliterate his name and memory from the entire history of the slave trade. With the exception of the Badagry highly-respected historian, Y.O. Avoseh, who mentioned in his book that Seriki Williams Abass was actively involved in the partitioning of the Gberefu Island in 1882 (Avoseh,1938)[7], I. A. Asiwajuwho dealt extensively with some of the achievements of SerikiAbassin his authoritative book (Asiwaju,1975)[8], and OlaideMesewaku et al who mentioned that as one of most remarkable figures in the Badagry District, SerikiAbass' administration had twenty (20) salaried chiefs and thirty (30) police constables (Olaide-Mesewaku et al,2000)[9], no other publications has been devoted to looking at SerikiAbass and his contributions to the history of Badagry and the trans-Atlantic Slave Trade.

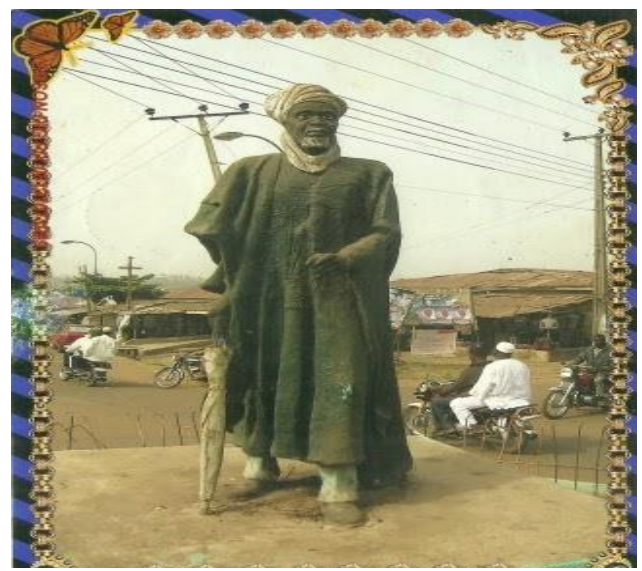

The statue of SerikiAbass at Ayetoro roundabout, Ogun State.

Aside from rigorous scholarship which has established the fact of the involvement of Western powers in the slave trade, there are also documents which confirmed that slavery was also practiced by the Africans among themselves before the trans-Atlantic Slave trade which made it a global enterprise. An estimated 173 city-states and kingdoms in Africa were affected by the nefarious trade. No less than 68 of these kingdoms could be 
described as nation states considering their well-established political and military structures, which gave them advantage to dominate their neighbours and sell their captives into slavery. Together, these people were affected by the nefarious trade between 1502 and 1853. At the centre of these trades were local chiefs, acting with the support of foreign collaborators, to promote the trade which come to assume the status of a by-product of tribal warfare, often fuelled by the same local chief and kings to serve their purpose (Rogers,1975; Mark,1997;Emmer,1998;Klein \& Klein,1999;Lovejoy,2000; Bradley and Carledge,2011)[10][11][12][13][14][15]. It was during this dark period that SerikiAbass was born and named Ifaremi by his parents in JogaOrile in Ilaro district, Ogun State, Nigeria.At the time of his birth, about three decisive wars were fought by the Yoruba subgroups, the most significant being the Egbas against the Dahomeans (Abomey). At that time, the economy of Dahomey was based on slave trade, the sustainability of which was threatened by the Slave Abolitionists. Many Yoruba towns and villages were overrun and destroyed by the rampaging Dahomean forces, many people were captured, enslaved in Abomey and sold into slavery through the slave port at Whydah (Ouidah) and Porto Novo in the present day, Republic of Benin (Biobaku,1957; Ajayi\& Smith,1964; Akintoye,1971)[16][17]. Ifaremi was captured in one of such raids by a Dahomean slave dealer and renamed Abass. But he was later resold to another dealer, a Brazilian known by the name, William, from whom he got his middle name since slaves had no identity but only "exist" on the account of theirowners.

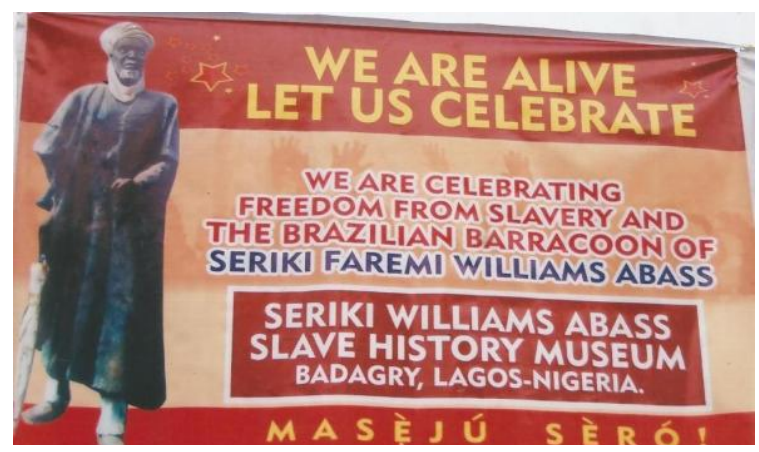

\section{A Poster commemorating the Abolition of Slave Trade in Badagry.}

On arrival in Brazil,William made the young IfaremiAbass a domestic slave and taught him how to speak and write English, Dutch, Portuguese and Spanish. This knowledge proved to be very valuable and gave him an edge over other slaves. He was returned to Nigeria, as Williams' representative and took care of his master's business. On his arrival, IfaremiAbass William first settled at Ofin, IsaleEko (Lagos Island) beforerelocating to Badagry in the 1830s, althoughBadagry was not entirely newto him,having visited Porto Novo and done business in most parts of the Egbado territories previously. He was the first person to own a lorryin the whole of the Egbado Division--- the Seriki Ford, which he bought in 1919 to ply the Abeokuta-Aiyetoro road (Asiwaju,163). He also made legitimate business transactions with European companies such as G.L.Gaisei and Witt and Busch; and Henry Pooley and Sons Ltd, a mechanical engineering company specialising in the manufacture of weighing machines located inBirmingham, England to name a few.

SerikiFaremi William was an active politician and Muslim leader. At the promulgation of the Native Council Ordinance in 1901 which was presided over by Governor MacGregor in Lagos, SerikiAbass was appointed the Paramount Chief in the Badagry District and later the Paramount Ruler of Badagry and the Western District in 1913 under the Indirect Rule. He retained the title when the region transformed into Ilaro Division of Abeokuta Province in 1914, presided as the "Senior Chief Ilaro Division" and, as the president of the Ilaro Divisional Native Authority, he was involved in the crowning process of Alase of Ilase and Onibooro of Ibooro. By 1918, he had become the president of the Native Courts in Ilaro, Addo, Idogo, Egbado, Eggua, OkeOdan, Ipokia among others (Asiwaju,75-103). He alsocontributed immensely to the growth of Islam in Badagry. After accepting Islam, he changed his name to Sanni although this was not as popular as the title he was bestowed later by the Muslim community. He led the team that renovated the second mosque in Badagry in 1877, and was named the SerikiMusulumi in 1895, the same year he was appointed the political ruler of Badagry by Major J. E. Ewart. He built the Sango Central mosque in 1896, a year before he became the SerikiMusulumiof Badagy. In 1897, he became SerikiMusulumi of the whole of western Yorubaland and the 
Egbado District (Falola,249). He led the Badagry Muslims delegation that petitioned Acting Governor Denton to establish a Muslim School in Badagry in April,1899. Before his death on June 11, 1919, SerikiWilliam Abass had established himself as the forerunner and founder of Yoruba towns such as Idogo and Ayetorowhich was established to provide shelter and protection for Yorubas displaced during the Yoruba Civil Wars(Ojo-Lanre,289)[18]. He was referred to as SerikiAbass of Badagry and SerikiAbass of Ayetoro due to his immense contribution to the establishment and development of both towns.From an obscure slave and captive, SerikilfaremiAbass William rose to become the father of "nations," whose statue stands today at Ayetoro, as a reminder of the human will to survive and stretch itself beyond tragedy.At his death in 1919, he was buried inside the Baracoon as if to emphasize that both the man and his slave relic are united, which is indeed true of their joint history.

\section{THE BARACOON OF 40 SLAVES}

The history of Badagy shows that the early slave market established at Posuko was abolished in the 1880s but replaced by another,Obada Market, which was established between Asago and Awhanjigo wards and at Hunto. An estimated $£ 50,000$ from the colony development fund was said to have been used in building the market which was formally opened in July 1954 by the late Akran of Badagry, AholuJiwa II, who was also an Action Group chieftain and Minster of Community Development in the Western Region. Due to congestion, the market was later relocated to Agbalata (Falola,251). However, SerikiAbassBaracoon of 40 Slaves preceded the construction of this market and has ironically survived it.Said to be where SerikiAbass lived with his 128 wives and 144 children, out of which only 11 survived (Ojo-Lanre,28), the Baracoon remains a "living" testimony to the horrid activities in the annals of Black history

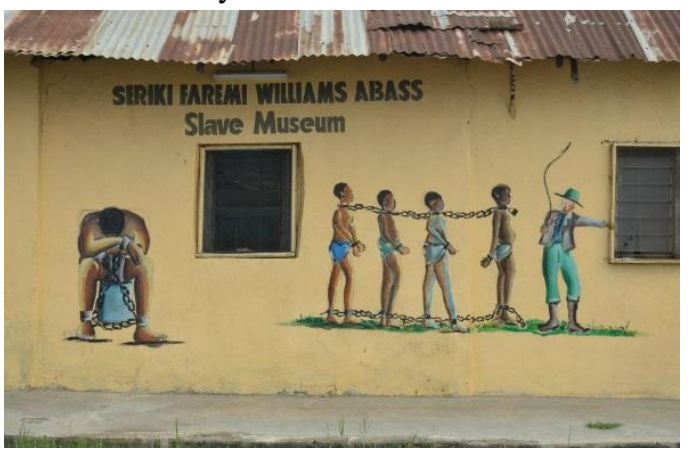

An artistic impression of Slaves and European Slave dealer on the wall of the Baracoon.

Located at a strategic spot, at the geographical coordinates of $6^{0} 250^{\prime}$ North, $2^{0} 530^{\prime}$ East, the Brazilian Barracoon/Slave Museum of SerikiAbass is on 125, Marina Road, beside the Badagry Post Office, Badagry, Lagos, directly facing the sea and the "Point of No Return". The Baracoon of 40 Slaves was the cell/rooms which housed both men and women (slaves) although kept in separate sections and rooms in the compound. Its name was derived from the Spanish word, Barracon, Barraca which originally meant a house built of wood and used by poor people. It was also called Barraque in French and Barracoon in English, and became popular during the slave trade as a sort of barrack or slave cell. SerikiAbass' Baracoon was said to have been built in 1840 although no specific written records support this claim. But what is certain is that it was built of burnt bricks, corrugated iron sheets and other items imported from Brazil. SerikiAbass also used the building todemonstrate his taste and influence as a wealthy merchant of repute during that time. In the same rooms were kept signs of SerikiAbass'deals as the General Manager of Brazilian and German companies such as G.L Gaisei, Witt and Busch with whom he dealt as earlier mentioned.

The Baracoon is made up of 40 rooms that housed 40 slaves each, with an inspection room which measured nine feet by nine ( $9 \mathrm{ft}$ by $9 \mathrm{ft}$ ), and an adjoining room of the same size but with a smaller window that is no more than a computer monitor in size and served as the only source of ventilation. In another room which appeared to be an office (SerikiAbass') were 10 pictures hanging on the wall and a glass shelf. One of the pictures shows SerikiAbass with his turban as the SerikiMusulumi of Badagry and another one when he was handed the staff of office as the Paramount Ruler of Badagry and the Egbado District. On the ground are heavy chains used to shackle the slaves to the walls, and by side of these chains are iron drilling bits that were used to brand the slaves for recognition. Although there has not been any generally accepted figure and number of people sold into slavery, the Baracoon of 40 Slaves remains one of the telling testimonies to the historical reality 
of the trans-Atlantic Slave Trade. These slaves also cut across many sociocultural strata of the ancient societies: some are criminals serving time in prison, some are innocent people captured on their farms, while some others were prisoners of war. Whatever their circumstance, once they were captured, they were taken to Europe, Brazil and the United States of America and the New World through the Point of No Return. The Vlekete Market in Badagry was a booming market and trade centre for slaves captured in the West coast during the time and was a few hundred metres from the Baracoon.

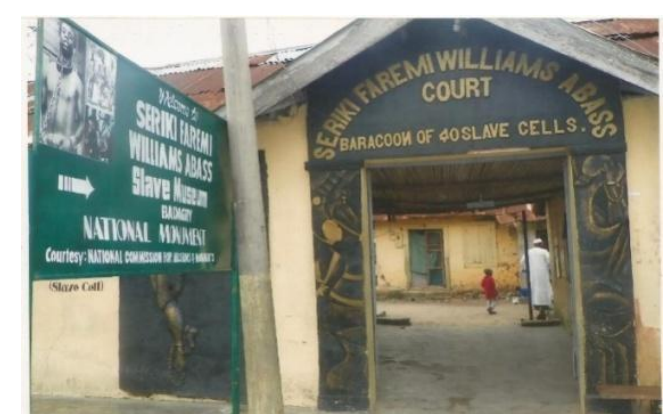

Entrance to the Seriki William AbassBaracoon of 40 Slaves, Badagry.

\section{POINT OF NO RETURN}

Closely linked to both the story of SerikiAbass and the Baracoon of 40 Slaves is the Point of No Return, named because it was the last point of contact between captured and sold slaves and their homes. At the middle of this bushy and narrow path is a well of about nine (9) feet deep said to have been dug sometime in 1840. The slaves were forced to drink from the well which was also believed to have been prepared with powerful charms. Upon drinking from the well, the slaves are said to lose their memory. On this particular well is written "Recitation by the Sold Slaves"

I am leaving this land;

My spirit leaves with me.

I shall not come back now, my shackles do not break.

It is the shackles that hold a ship down.

My ancestors bear me witness, I shall not return.

This land departs; my soul does not revolt.

My spirit goes along with me. I depart to that land unknown.

I shall not return.

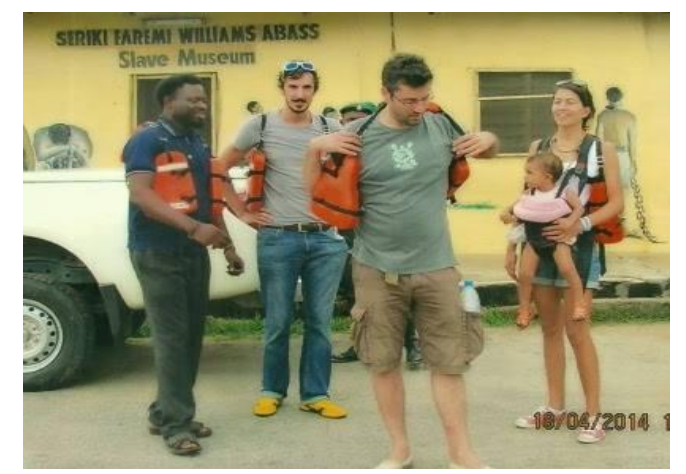

Anago conducting foreign tourists round the Baracoon

African chiefs and native heads served as middlemen for Europeans who needed the slaves to work on their plantations and were provided this human manpower in exchange for materials as cheap and embarrassing as mirrors, umbrellas and utensils: a huge umbrella exchanged for 40 slaves, plates and mugs exchanged for 10 slaves, gin bottles for 5 slaves, mirror for 10 slaves and above depending on its quality. There are many of such implements and relics in SerikiAbass compound today. 


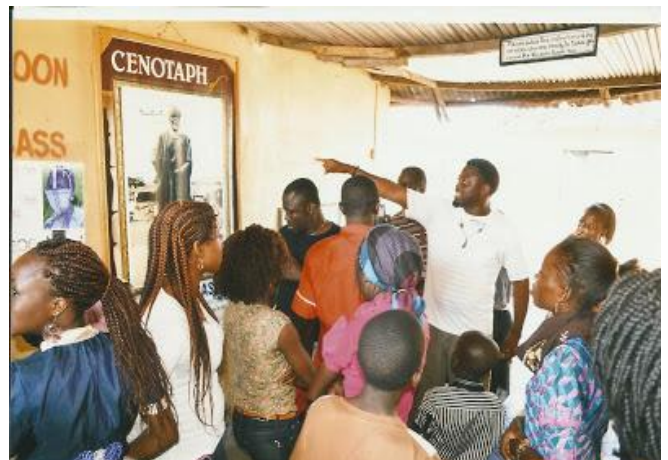

Anago with another set of tourists in the Baracoon.

\section{CONCLUSION}

From the Senegambia, through the Upper Guinea, Gold Coast, Bight of Benin, Bight of Biafra to West Central Africa and the South-eastern Africa where the trans-Atlantic Slave Trade swept across like a terrible wind, SerikiAbass and his BrazillianBaracoon of 40 slaves remain the most telling concrete reality of the sad past. Although Badagry continues to forge ahead as a community of peace-loving people today, together with their challenges and frailties, the memory of the slave trade certainly forms part of that ancient, yet, new beginnings.. Although a green signboard stating that the building has been taken over by the National Commission for Museums and Monument is erected at the entrance to the Baracoon today, not much seems to have changed. People have turned the rooms into residential quarters while the compound needs urgent refurbishment in order to sustain this edifice of immense historical significance.One could only hope that the government, which had taken the first step to naming the SerikiAbassBaracoon a site of historical essence, would do more in terms of funding in order to ensure that such an important historical relic is properly preserved.

\section{WORKS CITED}

[1] Byerman, Keith.(2005) Remembering the Past in Contemporary African American Fiction.(USA: The University of North Carolina Press,2005).

[2] Falola, Toyin. "The Minor Works of T.O. Avoseh" History in Africa, vol.19, Cambridge University Press, 1992): 237-62

[3] Biobaku, S.O. The Egbas and their Neighbours, 1842-1872(Oxford,1975).

[4] Ayantuga, O. O. "Ijebu and its Neighbours, 1801-1941" PhD dissertation. (University of London,1965).

[5] Folayan, Kola. "Egbado and the Yoruba-Aja Power Politics,1832-1894" (MA, thesis, University of Ibadan, 1967).

[6] Law, Robin.The Oyo Empire,c.1600_c.1836: A West African Imperialism in the Era of the Atlantic Slave Trade(Oxford: Oxford University Press,1977).

[7] Avoseh, TheophilusOlabode. A Short History of Badagry (1938).

[8] Asiwaju, A. I. Western Yorubaland under European rule,1889-1945 (1975).

[9] Olaide-Mesewaku, A. Babatunde, Peter Olaide-Mesewaku and Sola Adeyemi. Badagry: the cultural heritage. (Lagos: African Renaissance Foundation,2000).

[10] Rogers, Anstey.The Atlantic Slave Trade and British abolition,1760-1810(London: Macmillan,1975).

[11] Mark, Ferro. Colonization: A Global History(Routledge,1997).

[12] Emmer, P.C. The Dutch in the Atlantic Economy, 1580-1880: Trade, Slavery and Emancipation, 1998.

[13] Klein, S. Herbert \& Jacob Klein.The Atlantic Slave Trade(Cambridge University Press, 1998).

[14] Lovejoy, E. Paul. Transformations in Slavery (Cambridge University Press,2000):

[15] Bradley, Keith and Paul Cartledge.The Cambridge World History of Slavery(Cambridge University Press,2011).

[16] Ajayi, J.F. Ade and Smith, R. Yoruba warfare in the Nineteenth Century.(Cambridge,1964).

[17] Akintoye, S.A. Revolution and Power Politics in Yorubaland,1840-1893(London,1971).

[18] Ojo-Lanre, Wale. "Tribune Tourism: An encounter with Anago at SerikiAbass Slave Museum" The Nigerian Tribune, 2014: 28-9. 